\title{
Grzecznie i niegrzecznie w weselnych oracjach. Od konkurów do zrękowin
}

Małgorzata Trębska 
ntAPnS Seria X 20)4

\section{Małgorzata Trębska}

\section{Grzecznie i niegrzecznie w weselnych oracjach. Od konkurów do zrękowin}

W

Tesele szlacheckie to barwny i nadzwyczaj interesujący ceremoniał, w czasie którego między reprezentantami stron narzeczonych odbywal się krasomówczy dialog, co nadawalo obrzędom charakter teatralny'. Poszczególne kwestie dialogu byly przygotowywane i wygłaszane zgodnie z obowiązującymi ówcześnie regułami, z wielką dbałością zarówno o inwencyjną i elokucyjną atrakcyjność oracji, jak i actio. W czasie obrzędów związanych ze zmówinami, zrękowinami, ślubem czy przenosinami wygłaszano łącznic ponad trzydzieści odmian oracji weselnych. Byly to: prośba o pannę; odpowiedź ojca lub opiekuna (pozytywna, negatywna bądź odroczenie decyzji); dziękowanie za obietnicę panny; oddawanie pierścienia; dziękowanie za pierścień; oddawanie wieńca i dziękowanie za wieniec; witanie przyjeżdżającego pana młodego w polu (gdy reprezentant gospodarza wyjeżdżal kawalerowi na spotkanie); odpowiedź na to powitanie; witanie pana modego przez gospodarza; odpowiedź na to powitanie; oddawanie panny; dziękowanie za pannę; oddawanie upominków i dziękowanie za nie - z rozróżnieniem na mowy przy oddawaniu marcepanu i slodyczy, miednicy z nalewką (dzbanem), roztruchana (kielicha), kanaków, maneli, łańcucha itd.; oddawanie panny do łożnicy; dziękowanie za pannę; oddawanie kawalera i dziçkowanie za niego²; oddawanie księ-

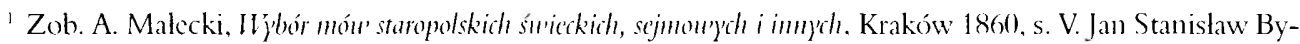
stroń uważa (nic wspominając o ustakeniach Maleckiego), że wescle przyponinato operę (por. J. S. Bystroń, Dzicje objezajón "u dannej Polsce. t. 2: Hiek. SI 1-XT 111. Warszawa 1976. s. 81). Katarzyna Mroczek sklania siç bardziej ku koncepcji dramatycznej niz operowej (zob. K. Mroczek, Epitalamium staropolskie'. Miedzy tradyejol literacka a drzeqdem n'eselmy'm. Wroclaw 1989. s. 49-54). Na ten temat takze M. Bartowska, Jerzy Ossolinski-orator

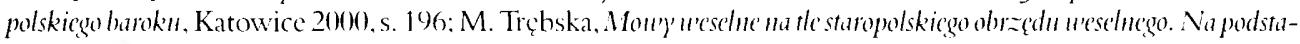

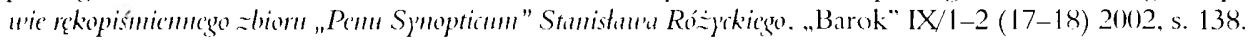

2 Oddawanic kawalera i dziçowanic za niego to prawdopodobnic rodzaj zabaw wesclnych. Możliwe, ze byly to mowy wyglaszane wylącznic na wesclach dworskich.
} 
gi weselnej i dziçkowanie za nią̧; w końcu życzenia po ślubie i dziękowanie za nie przez pana mlodego. Wszystkie te oracje wygłaszano oczywiście z pamięci, a przygotowanie ich bynajmniej nie było proste. Wertowano zatem herbarze, zbiory sentencji, przysłów i egzemplów, wspomagano się wzornikami i kompendiami retorycznymi oraz zapiskami w rodzinnych kodeksach. Mowy były dość długie, szczególnie oddawanie panny i dziękowanie za nią, które mogły liczyć nawet kilkanaście stron rękopisu. Obyczaj wymagal, aby w tych dwóch oracjach chwalono państwa młodych nie tylko za zalety osobiste, ale także, czy może przede wszystkim za znakomite pochodzenie i dokonania przodków, sięgając daleko wstecz i przywołując postaci historyczne lub calkiem legendarne. Clıwalono nie tylko przez grzeczność, bowiem na przykład funkcję laudacji panny można określić jako perswazyjną, gdyż jej głównym, podstawowym celem było utwierdzenie w kawalerze poczucia glębokiego szacunku dla małżonki i jej rodu. Przemówienia te miały wyjątkowy charakter, dlatego proszono o ich wygłoszenie osoby cieszące się szczególnym szacunkiem i obdarzone talentem oratorskim. Należy dodać, że mówca jako reprezentant strony mógl przysporzyć rodowi chwały, albo przeciwnie wzbudzić wielkie niezadowolenie, jeśli oracja nie została należycie przygotowana ${ }^{+}$. O znacznym zainteresowaniu tak treścią, jak i actio przemówień weselnych świadczą liczne komentarze w pamiętnikach staropolskich. Bardzo często znajdujemy w tych zapiskach miażdżącą krytykę nieudolnego mówcy weselnego, któremu wytyka się, że „wymowa” była szkolna, „podobna puerom”, „bez zbytniego utrudzenia mózgu”, odnotowuje się, że „kartka wspierała pamięć"

Zanim jednak mówcy mogli zacząć przygotowywać oracje o charakterze panegirycznym, zanim w ogóle podejmowano przygotowania do ślubu czy wesela, musiał zakończyć się proces konkurów, którego efekt nie zawsze był oczywisty i latwy do przewidzenia.

Mowy wygłaszane przy zalotach bardzo różnią się od tych prezentowanych już w trakcie samego wesela. Po pierwsze, ich charakter nie jest jednoznacznie demonstratywny. $\mathrm{O}$ ile

${ }^{3}$ Dotychczas nie znaleziono zapisów mowy przy dziçkowaniu za ksiçg̨ weselną. Można jednak przypuszczać, że taki typ istnial analogicznie do pozostalych.

+ O poczuciu odpowiedzialności oratora wescelnego nicch świadczy cytat: „Gdy chciałem opuścić króla, (...) zlecil mi, bym w poniedziałck [1 + IX] przckazal królowej jego dar ślubny wraz z przekazaniem uczuć królewskich w lacińskicj mowic. Dlugo siç wymawiakem. tłumacząc, że nie dość jestem uczony, nie wspominając już szczupłości czasu i braku panię̧ci. Racji tych uie przyj̧̧to, musialem więc podjąć ciężar, o czym niżej we wlaściwym duiu" (A. S. Radziwill, Pamiętnik o dziejach w' Polsce, tl. i opr. A. Przybós. R. Żelewski, t. 2. Warszawa 1980, s. 43). Radziwill miał na opracowanic mowy cztery dni. Jeszczc na chıwil̨̧ przed wręczenicm upominków przygotowywal siç do naznaczoncj mu roli i prawdopodobnic powtarzal tckst (zob. ibidem. s. 48). Opracowanic oracji zajmowalo wicke czasu. nic tylko gdy nowożcńcami byli królowic. Bazyli Rudomicz w swoim pamiçtniku równicż odnotowuje takic przygotowania retorycznc, które zajmowaly mu najczçściej jeden caly dzicń (zob. B. Rudomicz. Efemeros azyli Diarinsz pry'uatn' pisany' "'Zamościn u' latad 16.56-1672, tt. W. Foch, opr. L. L. Klementowski, t. 2, Lublin 20022. s. 1+1. 205, 250. $31+$ itd.).

"K. Sarnecki. Puniętnikiz cadsón" Jana Sobricskicgo. Diuriusz i relacje =lat 1691-1696. opr. J. Wolski. Wroclaw 1958, s. $327-328$.

${ }^{6}$ A. S. Radziw H. op. cit. s. 52.

Ibidcm. s. + tt.

${ }^{x}$ Ihidem. s. 51 .

"Ibidem. s. 52. 
przemówienia stricte weselne stanowią rodzaj komentarza do odbywających się obrzędów, co można powiedzieć z calą pewnością na przykład o wszystkich zespołach mów wyglaszanych przy oddawaniu upominków, to wniesienic prośby o pannę czy odpowiedź na tę prośbę (nièzależnie od tego, czy jest pozytywna, czy odmowna) nic pozostają jedynie popisem oratorskim. Sytuacja komunikacyjna jest bowiem zgoła odmiemna. Decyzje, których skutkiem jest późniejsze oddawanie panny, tu dopiero są werbalizowane, a oracje nie stanowią uzupełnienia obrzędu czy komentarza, a stwarzają pewną nową rzeczywistość.

Drugą bardzo ważną cechą różniąca mowy wyglaszane przy konkurach od przemówień weselnych jest struktura zespołów tematycznych. Zespolem tematycznym nazywamy tu orację i respons na nią, towarzyszące danemu obrzędowi, przy czym są to przeważnie stałe. symetryczne zespoly dwuelementowe, jak choćby: oddawanie panny, dziękowanie za pannę: oddawanie mancli, dziękowanie za manele itd. Zespół mów towarzyszących zalotom w przeciwieństwie do pozostałych cechuje się zmienną liczbą skladowych. Jest to zespót dynamiczny, gdyż na wniesienie prośby o pannę rodzic lub opiekum mógł odpowiedzieć w trojaki sposób: przychylając się do niej, prosząc o czas do nannysłu lub odmawiając. Mowy z tej grupy jako jedyne mają zatem wersje alternatywne responsu, podczas gdy pozostałe, o charakterze bardziej ceremoniahnym (mowy stricte weselne), uwzględniają tylko jedną odpowiedź. Decyzja rodzica lub opiekuna panny i mowa ją wyrażająca miała bardzo znamienne skutki dla przebiegu zalotów. Jeśli wyrażono zgodę na ślıb, szlachcic przemawiający w imieniu kawalera dziękował za obietnicę, jeśli natomiast odroczono decyzję, reprezentant kawalera ponawiał prośbę po jakimś czasie i czekal na odpowiedź, która znów mogła być trojaka. W końcu decyzja mogla być niekorzystma dla zalotnika, który to przypadek zostanie omówiony nieco niżej. Tak więc w zależności od rozwoju sytuacji zmieniała siç liczba mów: od jednej (prośba i gest symboliczny oznaczający odmowę, który mógł zastępować orację), przez dwie (prośba, odmowa), trzy (prośba, zgoda, dziękowanie), cztery (prośba, odroczenie decyzji, ponowienie prośby, zwerbalizowana odmowa), do pięciu (prośba, odroczenie decyzji, ponowienie prośby, zgoda, dziçkowanie). W skrajnych sytuacjach rodzice lub opickunowie mogli odraczać decyzję wielokrotnie, co dodatkowo komplikuje strukturę zespołu (zob. rys. 1).

Decyzja o wyborze kandydatki na żonę nie była łatwa, kawaler winien bowiem brać pod uwage jej status społeczny, majątek, zacność urodzenia, tradycje rodowe, w końcu także cechy osobiste potencjalnej malzonki: skromność, bogobojność, posłuszeństwo i pokorę, w ostateczności także urodę. Po podjęciu wstępnej decyzji przychodzil czas zalotów.

Maciej Dobracki w swoim poradniku zatytulowanym $W_{y}\left(w^{\prime}(m)\right)^{\prime}$ polit $)^{k^{10}}$ podaje kilka przykładów interesujących dialogów, które zakochany mlodzieniec mógłby wykorzystać w rozmowie z panna. Wydu'orny' polity'k to rodzaj rozmówek polsko-niemieckich, w których autor stara się przybliżyć swojemu czytelnikowi (cudzoziemcowi) polską kulturę i obyczaj. Jak się jednak okazuje, nie zawsze jego propozycje wzorów grzecznych rozmów można uznać za przystające do XVII-wiecznych konwenansów:

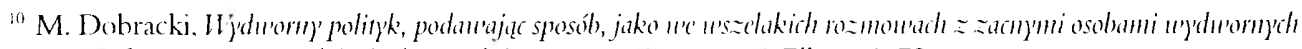

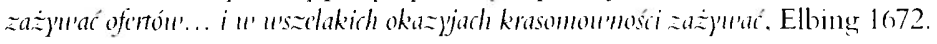




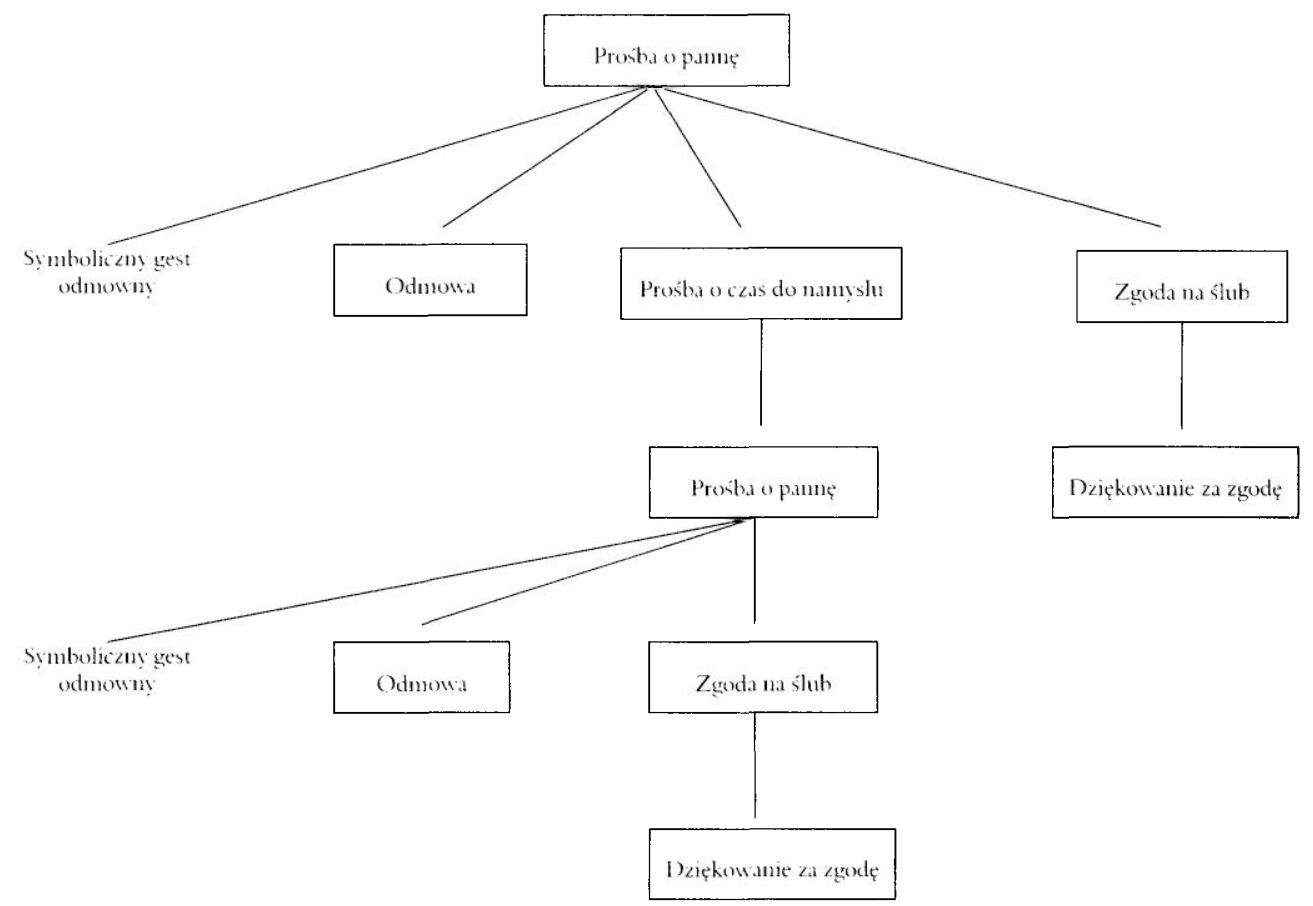

Rys. 1. Schemat zespolu mów wyglaszanych przy wnoszeniu prośby o pannę

Wspaniałe (wysokie) ${ }^{11}$ W[asz]M[ość] M[nie] M[iłościwej] Panny cnoty, anielski wzrost, tudzież bystrolotne, niebieskiego koloru nieprzystępne z siebie wydawając promienie (które nad wszystkie jaśniejsze gwiazdy) oko, taki we mnie przystojnej miłości wznieciło zapal, taką we mnie wszczepily milość, że lubo mi moja wiadoma błahość, przecie się jednak poważam najniższe moje WM MM Pannie oddać i prezentować usługi, uniżenie upraszając, racz, WMć MM Panno, tę tak gorącą do oddania uprzejmych sluźb moich ochotę w milościwej lasce swej chować, a mnie za najniższego sługę swego przyjąćc ${ }^{12}$.

Cytowana mowa nie ma charakteru oficjalnego, nie jest w żaden sposób związana z ceremonią, pozostaje poza schematem. Kawaler zwraca się w niej bezpośrednio do panny w sytuacji dość intymnej, będąc prawdopodobnie sam na sam, bowiem w obecności osób trzecich przemawialby do rodzica, brata czy innego opiekuna. To rodzaj flirtu, konwencjonalnego oddania się do usług czy, jak nazywa to sam Dobracki, „oferty z fraucymerem”. Autor poradnika podaje kilka różnych wersji odpowiedzi; jedna z nich cechuje się znaczną ostrożnością — panna wymawia się od przyjęcia takich usług:

\footnotetext{
I W nawiasach Dobracki podaje synonimy. aby czytelnik mógl wybrać słowo lub slowa bardziej według niego stosorvene.

M. Dobracki, op. cit., s. 138 .
} 
Mój Mości Panie. Tych, którymi WM MM Pan z ludzkości i wydworności swojej przypisować raczysz, przymiotów, ja sobie nie przyznawam, ani téz przyznawać dobrym prawem i tytułem noggę. Sługi zaś tak zacnego i potężniejszego (możniejszego) nad pana, który by pod zasłoną (ksztaltem) slugi wszystko pańskie opanować mógl (pod moc podbić), dobro przyjąć, jako nikomı, tak pogotowiu i mnie ani bezpieczna, ani dorzeczna. Zaczym wielce upraszam, niechaj to WM MM Pana nie obejdzie, gdy z tych niepotrzebnych shuzb i tak ścisłych obowiązków WMci MM Pana uwolniç, wszakże jednak życzliwa zawsze we wszelakiej czci i przystojności przyjaciólką i sługą zostanę ${ }^{13}$.

Trudno określić, czy panna odmawia szczerze, czy też podejmuje flirt, i tylko przyjmıje rolę niezdobytej i skromnej. Tekst jest tak skomponowany, ze jego znaczenie zmienia się w zależności od tonu i towarzyszących odpowiedzi gestów.

Drugi wzór daje już odpowiedź znacznie bardziej kategoryczıą. Panıa zdaje się wyczuwać, że młodzieniec może nie mieć szczerych i uczciwych wobec niej zamiarów:

Mój Mości Panie, uniżenie WMci MM Pana upraszan, racz mnie WMć MM Pan w tym z łaski swej ochronić, a tak wydwornymi i zbytnimn nie uciążać ofertami, które nie mej błalıej osobie, ale gaszkom (storzypiętkom) należą, którzy prostaczki niebogie pod zasłoną pojęcia za mąż sidlą, a pod nazwiskiem sług panami nad nimi być usitują (pragnią) ${ }^{1+}$.

Dobracki daje wzory wytwomych, jego zdaniem, rozmów, a jego bohaterowie, także panny, to osoby obyte, być może związane ze środowiskiem dworskim (lub przeciwnie: z mieszczanískim). Trudno sobie wyobrazić młodziutką szlachciankę, która z równą swobodą zachowywałaby się w towarzystwie płci przeciwnej. Autor zresztą sam przyznaje w Nocie, że większość z proponowanych przez niego zachowań, także werbalnych, w relacjach z ziemiańską córką uznano by za nieobyczajne czy nawet gorszące, zaś swobodna rozmowa między dwojgiem młodych lıdzi w przypadku panny stanı szlacheckiego jest niemożliwa ${ }^{15}$. Wszelkie bowiem prośby należało wnosić do mężczyzny: krewnego lub przyjaciela rodziny wyznaczonego w testamencie przez ojca na opiekuna. To on właśnie był osobą, która proszono o rękę panny i zgodę na ślub. Najczęściej czynił to zaufany przyjaciel, krewny kawalera lub

\footnotetext{
13 Ibide'm.

it Ibide'th, s. 138-140.

15 „To tu panniçtna i uwagi godna, że się w Polszcze takic offerty, ile $w$ donnach szlacheckich i w inszych wysokiego urodzenia stanacl. prywatnic i osobnic z panna pana mlodego nic obchodzą ani odprawują. Bo lubo mlodzian u stolu i w tańcu do panny mówić, o którą się stana, może. ona mu jednak i na tysiąc slów jednego nic odpowie. Calowania zaś za rzecz bardzo szpetną i obrzydliwą mają. która cale u nich zniesiona. Ale gdy pannę wypraszają. to przez dwóch do rodziców zeslanych poważnych i mądrych kawalerów. 1)opiero jeżeli siç rodzicom osoba uda [spodoba - przyp. M. T.|, tedy i panna córka na wolą i zdanie rodziców swycle przypada. Potym po obiccaniu panny, spisawszy kontrakty, jadą do zapisów, które w grodzic roborują |zatwierdzają przyp. M. T.\}. Dopicro pannic wolno dyskurować (rozprawiać) z mlodziancm, przyszlym malzonkicm swoim, obyczajnic jednak i skrommic, ale samej osobic z nim szpacirować. żarty ladajakic stroić (przechadzki czynić) nic wolno, bo to tam za wicjskį i bardzo szpetmą sztukę poczytają." (ibide'm, s. 1+t).
} 
osoba ciesząca sic̨ danym środowisku poważaniem i szacunkiem "'. Adresatką mowy mogła być jednak również kobieta, na przykład owdowiała lub wysokiego rodu matka panny, albo królowa lub żona magnata, jeśli panna została oddana na jej dwór na wychowanie ${ }^{17}$.

Prowadzona kwerenda nie wykazala dużej liczby rękopiśmiennych przekazów mów historycznych tej odmiany, jednak wystarczająco licznie jest ona reprezentowana w kompendiach drukowanych, przede wszystkim w Spizanni aktón rozmaitych ${ }^{18}$, Przedmou'ach ueselnych

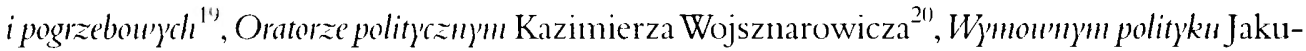
ba Boczyłowicza ${ }^{21}$ i Móu'cy polskim Jana Pisarskiego ${ }^{22}$. Na podstawie tych wzorników można odtworzyć schemat kompozycyjny oracji, na który składa się: egzordium o charakterze refleksyjnym (mówca snuje rozważania na przykład nad niedostatkami plynącymi z samotności lub dobrodziejstwann stanu małzeńskiego); krótki i ogólnikowy enkomion domu panny, stanowiący niejako uzasadnienie wyboru dokonanego przez kawalera; pochwała kandydata, co niewątpliwie miało być argumentem za przyjęciém prośby; i na koniec najważniejsza część prośba właściwa ${ }^{23}$. Autorzy wzorów, dla których najważniejszy jest przede wszystkim wymiar praktyczny ich dzieł, starają się przewidzieć wiele rozmaitych sytuacji życiowych: gdy rodzina konkurenta nie jest znana gospodarzowi lub gdy kawaler wypowiada się we własnym imieniu. Badacze obrzędu weselnego podkreślają bierność zalotnika²+ Tymczasem XVII-wieczny znawca tematu i autor wzornika, Jan Pisarski, podaje dwa wzory próśb, które wnosi we własnym imieniu sam kawaler. Oto końcowy fragment takiego wzoru:

Mam nadzieję, że WM Pan, w liczbę uniżonych shug i wiernych przyjaciól swoich muie przyjąwszy, utrapione już długą ekspektatywą serce - wielki bo-

\footnotetext{
1th Znane saj jednak przypadki, kicdy to kobicta wnosila prośbç o rękę panny (zob. K. Sarnecki, op. cit., s. 161).

${ }^{17}$ Na przyklad mowa Krzysztofa Zbaraskicgo. koniuszego koronnego (zob. J. Pisarski. Móu'ca polski albo suple-

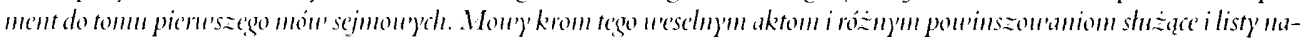

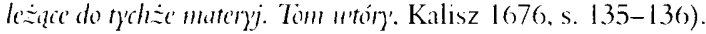

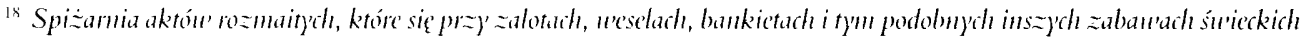
odpran'ou'ú́ zu'jkty'... Kraków 1632. Spizarnia nkazala siç lącznic piçtnaścic razy, w latach: 16.33, 1635, 1636. $1638,16+1), 16+1,16+2,16+5,16+7,1650.1655 .1660), 1668,1680$.

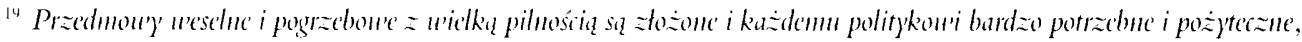
Kraków 1630.

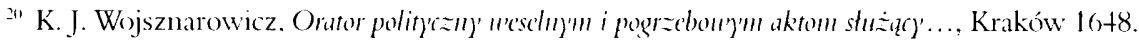

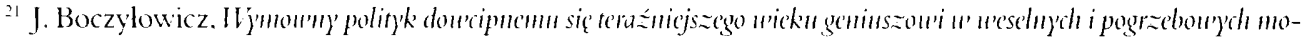
madi... akomodow'an', Warszawa 1674.

22 J. Pisarski. op. cit.

23 Kazimierz Wojsznarowicz, który pogrupowal teksty wzorów w kolcjności nie tyle chronologiczncj, co tematyczncj, calkowicie ponija zalecenic kawalera i cnkomion panny młodej. koncentrując się na wyrażaniu uczuć młodzicnica (K. Wojsznarowicz. op. cit.). Być możc jest to jednak spowodowane pewną sylwicznością jego propozycji. Szerzej o kompendinum Wojsznarowicza zob. M. Barlowska. Przedmou'y' "u' staropolskich zbio-

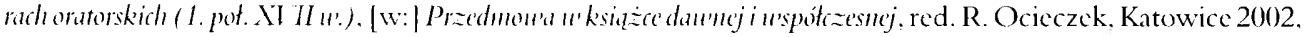
s. $75-85$.

${ }^{24}$ Jan Stanislaw Bystron (op. cit. s. 8.3) pisze, ze przy swatach kawaler byl nieobecny; równicż Katarzyna Mroczek (op. cit..s. 5+) podkreśla. żc mówcą winic n być dzicwosłąb. Bronisław Nadolski precyzujc, żc kawaler nie moze być obecny jedynic przy ostatnicj oficjalncj mowic z tcj grupy — zob. B. Nadolski. W'stęp, [w:] W'jhór móu' staropolskich, opr. B. Nadolski, Wroclaw 1961 (13N I 175). s. LXXII.
} 
wiem desideranti animis cruciatus est [pragnący cierpi w duszy] - jako przedtym pocieszną obietnicą, tak teraz pożądanym a ostatnim zezwoleniem pocieszyć będziesz raczył, o co i powtómie ze wszelakia uniżonością moją czołem biję $e^{25}$.

Jest to ta część mowy, w której wyraża się bezpośrednio prośbę o zgodę na ślub. Konkurent przemawia we własnym imieniu, a jak należy wnioskować z tekstu, jest to prośba powtórna, a zatem wnoszona po uplynięciu czasu przeznaczonego na „deliberacyja”.

Przepięknym przykładem oracji, które nie mają w sobie cech mów dworskich, a mimo to urzekają autentycznością, są dwie prośby wniesione przez nieznanego blizej szlachcica ariańskiego, Bartosza Siemichowskiego, za jego synem Danielem o córkę Walentego Szmalca, jednego z największych autorytetów i organizatorów życia zborowego malopolskich socynian. Z całą prostotą i szczerością Siemichowski opowiada o swojej trosce o "rozrządzenie” syna, o jego dalszy los, i o pragnieniu, aby przyszłe malzeństwo ułatwiło Danielowi i tak trudną drogę do zbawienia. Topos małżeństwa jako sposobu na przyblizenie się do Boga występuje w tego typu oracjach dość często, zwhaszcza w przypadku mów innowierców:

Jest ta powinność każdego rodzica, aby potomstwo swoje, które mu Pan Bóg da, naprzód wprawil w bojaźń Bożą i w znajomość woli Jego ś[więtej], i w zachowanie przykazań Jego, a potem obmyślił i obradził przystojny i uczciwy sposób życia jego na świecie. (...) A inszego sposobu doskonalszego nic baczę, jedno ten jeden, który saun Pan Bóg ludziom podać i postanowić raczyl, to jest stan ś[więty] malżeński, który jest do postanowienia ludzkiego i do pobożnego życia na świecie osobną niejaką pomocą ${ }^{2 n}$.

Z równą szczerością zwierza się z poczynionych już kroków i z własnych rozterek:

Ale z drugiej strony dobrze mi się stało, że mię żona moja do WM uprzedziła (jako to pospolicie białogłowy bywają w sprawach swych gorętsze), i tego się WM Dobrodziejowi memu przez Je[j] Mość Panią Szczepanowską, co w sercu swoim miała, zwierzyła. O czym mi Je [i] Mość oznajmiła, że mi WM nie telko bliski przystęp w tej sprawie dawać raczysz, ale też i muilość swoję mi WM w tej sprawie ofiarować raczysz. Za to ja WM Dobrodzicjowi memu uniżenie dziękuję, a proszę, abyś mię WM i do końca z miłości swojej opuszczać nie raczył, a ja, jako za wszytkie łaski i dobrodziejstwa, tak osobliwic za to Dobrodziejowi memu odsługować zawżdy, póki mię Pan Bóg chować będzie, gotów być chcę, także i Ich Mościon wszytkim, którzy do tej sprawy należą ${ }^{27}$.

Siemichowski wprowadza do mowy elementy obce temı paradygmatowi gatunkowemu, co czyni orację mniej oficjalną, zblizoną nawet bardziej do zwyklej rozmowy niż oficjalnego

\footnotetext{
25 J. Pisarski, op. cit., s. 140-141.

26 Rkps Bibliotcki Narodowej w Warszawic, sygn. BN BOZ 823. k. 17+-175.

27 Ibidem.
} 
przemówienia. Uwagi o żonie czy „pani Szczepanowskiej” sprawiają wrażenie pewnej swobody wypowiedzi, co jednak silnie kontrastuje z patosem wstępu i uniżonością, z jaką zwraca się ojciec kawalera do Lubienieckiego. Siennichowski nie jest wytrawnym mówcą, z czego zdaje sobie sprawę, choć kilkakrotnie był proszony o wygłoszenie takiej lub innej oracji weselnej. Świadczy o tym poniższy cytat, będący fragmentem egzordium mowy wygloszonej do pozostalych opiekunów Smalciusówny:

Aczkolwiek zacne osoby WMciów M[nic] M[iłościwych] PP [Panów] i powaga, którą Pan Bóg WMciów znacznie ozdobić raczyl, poniekąd wstręt mi czynila i w beśpieczeństwie mię hamowała stawiania się mego z kauzą [sprawą] moją przed osoby WMciów MM PP, tudzież taż i mialka umiejętność moja, która częstokroć gaśnie i w subtelnicjszych, gdy przychodzi stanąć przed osobami ludzi tak wiclkich i mądrych, więc i ten niemaly wstręt był zamysłowi memu, i nieraz mię związal od przedsięwzięcia mego: i sam w niczym nie jest zasłużony WMciom MM PP, i lubo to ledwie jest wiadoma (oprócz B[rata] Pana Lubienieckiego) WMciom MM PP osoba moja i życie moje na świecie ${ }^{28}$.

Nieśmiałość, o której wspomina, nie jest jedynie kokieteryjną wersją toposu skromności, tak jak to bywa w przypadku znacznie późniejszych przemówień na przykład Andrzeja Załuskiego $^{27}$. Nie jest to tylko figura myśli, gdyż znajduje potwierdzenie w nieco chaotycznej, w porównaniu z innymi tekstami tego szlachcica, kompozycji wypowiedzi.

Dodatkowo te dwie mowy stanowią dowód na to, że pierwsze w strukturze zespołu wniesienie prośby mogło oznaczać de facto wygłoszenie dwóch przemówień, jeśli panna miala więcej niż jednego opiekuma. Odpowiedzią na prośbę mogło być wyrażenie zgody, odmowa lub odroczenie decyzji. W przypadku, gdy rodzina panny przystawała na uczynioną propozycję, wyglaszano krótką zazwyczaj orację, w której zawierały się elementy analogiczne do tych zawartych w prośbie. W większości przypadków proszono jednak o czas do namysłu. Mówca w takiej sytuacji musiał wykazać się niezmierną delikatnością, aby konkurent nie poczuł się urażony:

Teraz uniżenie Jegomości upraszam, aby salva anicitia [zachowując przyjaźń] respons na inszy czas odłożyć mi się godziło, żeby tak, przyjaciól imnych dołożywszy się, pleniori consensu [za zgodą wszystkich] żądaniu Jegomości dosyć mógł uczynić. Wszak to, co komu Bóg obiecal, minąć nie może ${ }^{30}$.

\footnotetext{
2k Ibidem, k. 175 r.-1".

29 Oracje wesclnc Andrzcja Chryzostoma Zaluskiego znajdụią siç między innymi w: J. Ostrowski-Daneykowicz. Su'ada hy'mencuszou'a. [w:] idem. Surada polska i tacinska albo miscellanea oratorskie..., Lublin 1745. Teksty to zostaly przedrukowanc z. Món rónych wydanych przez samego Zaluskiego i Món'c) polskiego (A. Ch. Zaluski,

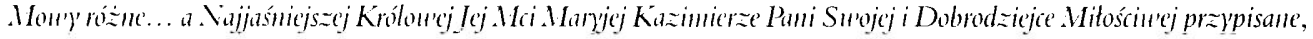
Warszawa 1690: I. Pisarski. op. cit.. s. 217-220).

"J. P'isarski. op. cit.. s. 151-152.
} 
Oracje tego typu, których wzory znajdujemy w Móu'cy polskim, mają następujący schemat kompozycyjny: egzordium jako wyrażenie wdzięczności za łaskę wyświadczoną przez kawalera, prośba o czas na zasięgnięcie rady krewnych i przyjaciól, uzasadnienie tej prośby i tradycyjne polecanie się do usług.

Cytowany tu juz Bartosz Siemichowski wita swoich gości z wielką rewerencją i szacunkiem, gdy wnoszą prośbę o rękę jego córki Anny.

Barzo mi jest mila i wdzięczna ta bytność WMciów MM PP i braciej, którą mi WM chęć uprzejmą swoję i ubogiemu donkowi menu wyświadczać raczycic, życząc mi za żywota mego nie telko rozrządzenia ubogiego domku mego, ale też i sposób, i drogę do rozrządzenia onego podawać mi raczycie. Nie upatruję w tym godności mojej żadnej, bo jej nie masz, ani też czuję tak być zasłıżonym WMciom i zacnemu domowi WMciów; abym kiedy na taką wielką miłość WMciów zarabiać mial, nie jest to w mej pamięci ${ }^{31}$.

Grzeczność, a nawet czołobitność Siemichowskiego znów nie jest jedynie konwencjonalnym zachowaniem, realizacja obowiązującego toposı. Szlachcic jest szczerze zaskoczony i onieśmielony wniesioną prośbą, o czyın, co charakterystyczne dla niego, mówi wprost:

Co się tknie już tej sprawy, iż na mię tak nagla przypadła, takem w niej zdzieciniał, że nie wiem, co bym w niej i jako sobie począć miał. Bo z jednej strony chęć do rozrządzenia ubogiego domku wiedzie mię, z drugiej bojaźń nie lada jaka miç hamuje, żebym w tej sprawie jako nieostrożnie i nierozmyślnie nie począt ${ }^{32}$.

"Zdziecinieć" nie jest z pewnością wyrażeniem należącym do stylu obowiązującego w takich mowach. Ojcu trudno jest podjąć decyzję, o czym informuje w zgoła odmienny niż prezentowany w Móu'cy polskim sposób. (ilośno też wyraża swoje myśli i obawy dotyczące słuszności ewentualnej decyzji, jakby niepomny, że mogą zostać wzięte za dyshonor dla kawalera i jego zasłużonej zborowi rodziny Sternackich. Bardzo ciekawym rozwiązaniem, które przyjmuje Siemichowski, jest odwrócenie ról. Ojciec proszony o rękę córki zwraca się prośbą o radę do samych swatów:

Jednak iż z WMciami bracią swoją miłą i kochaną mam teraz sprawę, a to Pana Boga wziąwszy na pomoc, WMciów tez jako spólnych przyjaciól przywziąwszy, WMciów samych się wprzód przed inszymi miłymi przyjacioły moimi radzę. A WM jako bracia moi ukochani, tak jako Pan Bóg do serca i sumnienia WMom podać raczyl, zdanie mi swoje raczcie powiedzieć, że tak zechcecie prowadzić, jako bym sobie począć mial'

\footnotetext{
${ }^{31}$ Rkps BN BOZ 823. s. 3601-361.

32 Ibidcm. s. 361 .

${ }_{33}$ Ibidcm, s. 361-362.
} 
To nietypowe zachowanie może tłmmaczyć fakt, że dziewosłębami byli bracia Otwinowscy, przyjaciele i protektorzy zboru, będący dla Siemichowskiego niewątpliwymi autorytetami. Zwraca uwagę fakt, ze ojciec panny tytułuje ich „bracią swoją miłą i kochaną”, a więc w sposób implikujący równość rozmówców, a jednocześnie przyznaje ich radzie pierwszeństwo przed wszystkimi innymi przyjaciółmi. Mowy Siemichowskiego wyróżniają się na tle innych oracji tego typu autentyzmem i prawdziwością uczuć, graniczącą nawet miejscami z niedbałością o decormm.

Cojednak w praktyce oznaczalo „wzięcie na deliberacyja”, jak określa Pisarski odroczenie decyzji? Jak wyglądaly owe narady rodzinne, niech świadczy tych kilka wyjątków z listów Krzysztofa Opalińskiego do brata Łukasza. Pierwszy fragment pochodzi z listu datowanego na 31 grudnia $16+3$ roku:

Niżeli list zamknę, przypomnieć j oznajmić zdało mi się WMPu, że w staraniu swym, albo raczej przez przyjaciela pytaniı się o Pannę Zofią, nie ustawa P. Ludwik Wajer. Nie dałem żadnego responsu cathegoricum [stanowczo], pokąd bym się nie zniósł z WMć Panem. Ja, lubo nie cale indino [przychylam się], a to jednak rozumiem, że by nieźle było. Czlowick grzeczny i dostatni, piéniężny (ma in paratis [gotówką] trzykroć sto tysięcy, które na Wieleń obrócić chce, jeśliby go mógł otrzymać), nuż starostwo waleckie 70000 infallibiliter [nieomylnie] czyni; na koniec poczekałby posagu, pokąd byśmy chcieli. Uważ tedy WMć wszystko, bo owa obiectio [sprzeciw] z strony domu, a cóż są nad nich Dynofowie, a przecie widziemy, z jakimi się powinowacą domani. To też WMć wiedz, że l'itac incorruptae [nieskazitelnego żywota] sam, a bracia wielkiéj w Prusiech reputacyi i u Króla laski. Między tymi konsyderacjami niech ta będzie niepoślednia, że nie wiem, czego będziemy czekać. Panna idzie w lata, ów od Koźmina milczy i zgola, Boże odpuść, kawi ${ }^{3+}$.

Prawie rok później bracia nadal radzą o losie klopotliwej siostry:

Pannę siostrę biorę z sobą, o której staranie ustawicznie placzącej, trzeba nam providere [zatroszczyć się]. Zgoła bliskości trzeba upatrować i inszych konsyderacyj, które, Bóg zna, gdy serio expendo [gruntownie rozważam], znajdą się w Wajerze. A jeśli ponowi (co serio zamyśla), nie widzę excusationi locum albo causam [miejsca ani przyczyny odmowy]. ،Clhłop hoży, parantella w Prusiech wielka, dostatek pański i condicio [stan, majątek]. Tu osięść chce w Wielgiéjpolszcze. Człowiek nierozrzutny, dexter [prawy], młodość swą przystojnie trawil etc. A Stuszka co? Litwin, suffficiat dixisse' [dość powiedzieć], i do Litwy żonę chce prowadzić (kędy, veteri verbo [wedle dawnego powiedzenia], żadnej cnotliwéj nie masz, a choćby też była, tedy ritio gentis [ haúbą rodı] kożdą obramują). Niż gdzie tam brat, gdzie siostra, gdzie ciotka, pokrewni, przyjaciele; ommia peregrina 
eterna, nola, compta [zawsze przybysz, nowa, zepsuta]. Zgola cicho o tym, przynajminiej dla Dworus ${ }^{35}$.

Po pewnym czasie młodzieniec ponawial prośbę, na którą gospodarz winien dać ostateczną odpowiedź. Pięknym przykładem oracji, łączącej w sobie cechy mowy wyrażającej zgodę na oddanie panny i mowy przy oddawania pierścienia, jest przemówienie, które w imieniu kanclerzyny Zamoyskiej wygłosił Jakub Sobieski. Przyjętym kawalerem, ubiegającym się rękę kanclerzanki, Gryzeldy Zamoyskiej, był Jeremi Wiśniowiecki. Do niego whaśnie Sobieski kierowat slowa:

W tak srogim żalu swym, którym nie tylko dotknęła, ale prawie przycisıęla ręka Pańska Jej Mść Panią Kanclerzynę Koronną, moję Mciwą Panią, tę jednę u siebie znajdıje pociechę: żywemu malżonkowi swemu wraz poprzysiçżone, i umarłemu oddawać zawsze posłuszeństwo święte, a wiedząc, iż ta intencyja i indonacyja jego byla dać w stan małżeński W. X. M. starszą córkę, Jej Mść Pannę Kanclerzankę Koronną, oto i w tym ona wprzód Boskiej, a potym małżonka swego stucha woli; za usilnym W. X. M. staraniem, za prośbą w tych dniach przez wielkie i zacne ludzie od W. X. M. wniesiona, obiecuje W. X. M. dnia dzisiejszego $(\ldots)$ córkę swoją ${ }^{3 t} \ldots$

Na szczególną uwage zasługuje wplecenie w tok mowy frazeologii i topiki przynależnej oracjom pogrzebowym. Przyczyny tego stają się oczywiste, jeśli weźmiemy pod uwagę okoliczności towarzyszące wniesieniu prośby o pannę. Mowa Sobieskiego datowana jest na 13 lıtego 1638 roku. 8 stycznia zınarl Tomasz Zamoyski, ojciec Gryzeldy, jego pogrzeb odbyl się 9 lutego, a zatem cztery dni przed zrękowinami. W wieku XVII załoba, nawet świeża, nie stanowila przeszkody w ubieganiu się o pannę i realizacji planów matrymonialnych, o czym świadczy na przykład fakt. że na pogrzebie krewnego Opalińskich wniesiono prośbę o Urszulę Opalińską w imieniu Andrzeja Grodzieckiego ${ }^{37}$, co z perspektywy współcześnie pojmowanych dobrych manier uchodziłoby co najmniej za nietakt. Radość i lzy smutku mieszały się zatem nie tylko w życiu, ale również w tekstach oracji. Obietnica dana Wiśniowieckiemu jest bowiem rodzajem konsolacji dla wdowy, która, oddając księciu swą córkę, wypehnia ostatnią wolę męża. "Srogi żal”, ciężar „ręki lańskiej” ctc. to motywy na stale wpisane w gatunki funeralne, tu jednak zostały wkomponowane w orację, która z zalożenia winna mieć charakter radosny, weselny. Zasadniczo Sobieski zachowuje wszystkie elementy kompozycyjne wyrazenia zgody na ślıb, dostosowuje jednak tekst do okoliczności, przy czym takie rozwiązania spotyka się w większości mów oddawania lub dzię̧owania za wdowę lub w imieniu wdowca.

35 Cyt. za: ibidertl, s. 240.

36 Rkps Zakładu Narodowego imienia Ossoliniskich we Wroctawiu. sygn. Ossol. +10). s. 190-192. O oracji tej wspomina między innymi Zofia Trawicka. nic poświçcając jej niestety szczególnicjszcj uwagi (por. Z. Trawic-

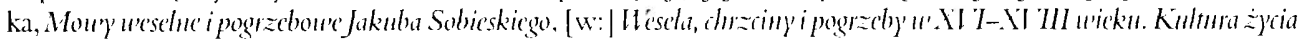
i śmieri, red. H. Suchojad, Warszawa 20(01, s. 173-174).

${ }^{37}$ Zob. K. Opaliníski, op. cit., s. 403. 
Jednym ze stałych członów wyrażenia zgody jest enkomion panny. Tu, mimo że koligacje i historia rodu dają podstawę do imponującej laudacji, mówca ogranicza się do pewnych ogólników, takich jak stwierdzenia:

...córkę, urodzenia z obojej: i z ojcowskiéj, i z macierzyńskiej linijej takiego, o jakim nie tylko W. X. M. wiedzieć raczysz, ale i wszytko wie chrześcijaństwo (...); córkę wychowania takiego, jakiemu się wszytka dziwıje Polska; córkę przymiotów, cnót i obyczajów takich, które się urodzeniu i wychowaniu jej równają; córkę, na ostatek rzekę, jedyne ojcowskie kochanie.

Ta pochwała, choć utrzymana w stosownej stylistyce, jest niezwykle krótka. Sobieski miał jednak sposobność pofolgować swym enkomiastycznym skłonnościom, gdy rok później, oddając pannę, wyglaszal orację na weselu Gryzeldy i Jeremiego ${ }^{38}$. W wyrażeniu zgody, tak jak we wszystkich niemal odmianach mów wypowiadanych w imieniu rodziny panny, zawiera się także formula zobowiązania kawalera do wdzięczności. Jakub Sobieski za tak hojny upominek kanclerzyny, jakim jest panna, żąda od Wiśniowieckiego oddania serca i gotowości do ushug domowi i rodzinie Zamoyskich. Na koniec, jako ostateczne przypieczętowanie danego słowa, przekazuje księciu pierścién, co czyni orację rodzajem kontaminacji paradygmatu wyrażenia zgody na ślub i oddawania pierścienia. Mowa Sobieskiego, w przeciwieństwie do przytaczanych wyżej mów Bartosza Siemichowskiego, jest bardzo jednorodna i konsekwentha stylistycznie, bogata i patetyczna, stosownie do rangi i pozycji narzeczonych.

Gdy rodzic lub opiekun wyraził zgodę na ślub, wówczas kawaler lub swat wygłaszał dziękowanie za obietnicę. Jeśli jednak odpowiedź miała być negatywna, udzielano jej w sposób subtelny, być może nie chcąc urazić bolesnymi słowy drażliwej dumy szlacheckiej. W literaturze przedmiotu czytamy o wieńcach grochowych wrzucanych ukradkiem do powozu kawalera lub wywieszanych na drzwiach, o czerninie, czyli czarnej polewce, o arbuzie, o ananasie albo o kaszy ze świńskimi ogonkanni, które w zależności od stopnia i kierunku wygięcia oznaczają odmowę lub zgodę ${ }^{39}$. Katarzyna Mroczek nawet wyraźnie pisze, że odmowy nie dokonywano stownie, ale właśnie uciekając się do tych powszechnie rozumianych gestów ${ }^{+1}$. Jednak, jak można wnioskować znów z nieocenionego dzicla Jana Pisarskiego, rekuza mogla zostać sformułowana w oparciu o następujący schemat: egzordium o charakterze refleksyjnym; enkomion - pochwała kawalera, której funkcję można określić jako amplifikację żalu wywolanego koniecznością odmowy; w końcu odmowa wlaściwa i wyrażenie nadziei na zachowanie wzajenmego szacunku i sympatii.

\footnotetext{
is Oracja wygloszona przy oddawaniu Gryzeldy Zamoyskicj zostala wydrukowana w Surıdzie polskiej J. Ostrowskicgo-Dancykowicza (op. cit., s. 75-83).

in Por. J. S. Bystroni, op. cit., s. 83.

t) Por. K. Mroczck, op. cit., s. $5+$.
} 
Tu dialog ulegat przerwaniu; trudno zresztį wyobrazić sobie tekst oracji wygloszonej bezpośrednio po odmowie ${ }^{+1}$. Dopiero po pewnym czasie, jeśli panna nie zostala wydana za mąż, kawaler mógł ponownie wniéść prośbę, i cały dialog ulegał wznowieniu. Odnowa jednak była traktowana bardzo poważnie, i niejednokrotnie powodowała ģ̨̨̧okie urazy i zadrażnienia między kandydatem i jego rodem a rodzina panny, o czym świadczą najlepiej zapiski Albrychta Stanisława Radziwiłla ${ }^{+2}$ czy Jana Chryzostoma Paska ${ }^{+3}$.

Wymienione w artykule odmiany oracji nie wyczerpują bynajmnicj repertuaru przemówień wyglaszanych od konkurów do zrękowin. Okoliczności wymagały, by kawaler ofiarowywal wybranej pannie, a później narzeczonej, prezenty, z których jedne miały głównie wartość symboliczną, inne zaś łączyły funkcję symbolu z realną wartością przedmiotu. Oczywiście każdemu podarunkowi towarzyszyly oracje, co w praktyce oznacza, że w zespole mów związanych z prośbą o pannę można wyróżnić osobne podzespoly, szczególnie dotyczące ofiarowywania upominków. 1)o prezentów wręczanych jeszcze przed ślubem zaliczyć należy przede wszystkim pierścień, a także wieniec, który mógl być uwity z rozmarynu, róż lıb innych roślin, albo wykonany z drogocennego kruszcu i ozdobiony klejnotani ${ }^{+t}$. W tekstach nów zawartych w kodeksach rękopiśmiennych w żaden sposób nie zaznacza się okoliczności wręczania wieńca, natomiast z kompendium Orator polityezm)' Wojsznarowicza wynika, że czyniono to przy wnoszeniu prośby o pannę (..starając się o przyjaźú”), bezpośrednio po zrękowinach lub tuż przed sanym ślubem (przy czym tytuly przykładowych mów każdorazowo precyzują sytuację). Mowy te zasadniczo niewiele różniły siç od oracji wyghaszanych tuz przed ślubem, gdyż topika ich związana byla najczęściej z ksztaltem wieńca (koło jako symbol wieczności) albo z właściwościami kwiatów, z których został spleciony (zapach, ksztalt czy fakt, że dana roślina nie zrzıca liści na zimı̨), jednak (co wynika z poniższych dwóch fragmentów) zawierały też sygnały wyraźnie świadczące o przeznaczeniu wzorów:

Ten wieniec, nie z beksanowego [kwiatu — przyp. M. T.] wprawdzie liści uwity, ale bojaźnią wszytek przeplatany, obawia się, aby dobrej przyjaźni nie szwankowały zadatki, umacnia go jednak skłonny W[aszmość] M[nie] M[iłościwej] Panny afekt. Rozumien, ze w przedsięwziçciu Jego M[ości] Pana N. barziej umocni, gdy go, WMM Panno, z milą od niego ten wieniec odbierzesz ochotą ${ }^{45}$.

Jego Mość Pan N., nie chcąc od pospolitego zdrożyć zwyczaju, WMM Pannie ten przesyła wieniec, wiedząc, iż najlepszą ku ulżeniu tęsknoty jest receptą. A ja w tym nie wątpię, iż WMM Panna tą blahą Jego Mości nie wzgardzisz usługą,

\footnotetext{
"Dotychezasowa kwerenda nie przyniosla ani jednego przekazu takiego przenówienia; z ostatecznymi konstatacjami należy siç jodnak wstrzynać do czasu ukoniczenia badań.

t2 A. S. Radziwill. op. cit., s. 57 (27 września 16.37): s. $61-63$ (7 i s paździcrnika 1637): s. 85 (3 kwietnia 1638).

13 Zob. J. Ch. Pasck, Pamiçmiki, opr. W. C.zapliński, t. 2. Wrockaw 2003, +29-431.

+H Zob. K. Mroczek, op. cit., s. 57-58; M. Trębska, op. cit., s. 136.

t5 K. Wojsznarowicz, op. cit. s. 19-20.
} 
owszem, latwo z serca wypędzisz tęsknotę, gdy, ogrodowe rozwijając kwiecia, serdeczną afektu Jego M[ości] rozwiniesz życzliwośćt ${ }^{+1,}$.

Oba powyższe wzory przeznaczono do wygłoszenia po zrękowinach, a zatem na pewien czas przed ślubem. W pierwszym mówca motywuje of iarowanie wieńca chęcią utwierdzenia uczuć zarówno panny, jak i samego kawalera. Przyjęcie podarku ma być bowiem sygnałem ostatecznej zgody, sposobem wyrażenia przychylności narzeczonemu. Wyrażenie obawy przyszłego pana młodego co do stałości afektu nie pojawia się często w oracjach tej odmiany. Wynika to prawdopodobnie z faktu, że większość przekazów takich mów dotyczy wręczania wieńca tıż przed ślubem, gdy zmiana decyzji jest już znacznie mniej prawdopodobna, choć oczywiście w oracji autorstwa Wojsznarowicza można jedynie mówić o pewnej konwencji. W drugim przykładzie wieniec, jako symbol wiecznych uczuć, staje się „ku ulżeniu tęsknoty receptą", a zatem pełni zgoła odmienną funkcję niz w pierwszym cytowanym fragmencie. Nie jest już sposobem na sprawdzenie i potwierdzenie uczuć, ale ukojeniem dla zniecierpliwionego długim oczekiwaniem serca. „Tęsknota” również wskazıje na pewien dystans czasowy, który dzieli narzeczonych od spetnienia, co pozycjonuje ten wzór jednoznacznie w chronologii obrzędów zaręczynowych i weselnych.

Omawiane wyżej elementy precyzujące przeznaczenie tekstu oracji pojawiają się w mowach niezmiernie rzadko. Znacznie częściej wskazıją na innego typu okoliczności towarzyszące wręczaniu wieńca, na przykład święto patronki panny młodej lub określoną porę roku (jeśli się o niej wspomina, jest to najczęściej zima). Rzadko też są tak jednoznaczne i oczywiste, gdyż w większości wzorów proponowanych choćby przez Wojsznarowicza trudno określić, na jakiej podstawie dany tekst zostal przez autora przyporządkowany do kategorii „starając się o przyjaźn”, „przy zrękowinach” czy „przed ślubem”.

Pierścienie tradycyjnie wymieniano w czasie zrękowin, przy czym topika oracji związana była ściśle z ksztaltem obrączki (traktowanym jako koło Fortuny, symbol wieczności, lecz także znak zniewolenia lub przeciwnie - władzy, etc.) i właściwościami klejnotu (kolor, wartość, przypisywane własności uzdrawiające lub magiczne). Dla przykladu, Spizamia aktón rozmaity'ch zawiera wzory oracji z odróżnieniem mów wygłaszanych przy oddawaniu: diamentu, rubinu, szafiru, szmaragdu, jaspisu i turkusów ${ }^{+7}$. Poniższy fragment wzoru autor Oratora poli-

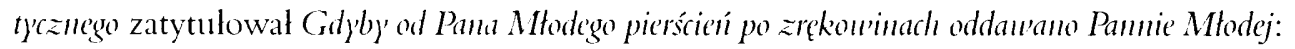

Na tym pierścieniu snadno WMM Pani zwojowanego JM Pana $N$. rozeznać możesz serca tryumfy, gdzie je szczęśliwie za powodem błogosławieństwa Pańskiego na tym będziesz rozwodzila palcu, kędy szczerej zależy tryumf dokonać przyjaźni. Który, nim szczęśliwego dojdzie terminu, dziś się w tym oddawa pierścieniu, abyś, na obecne patrząc pobojowiska, zholdowanego swym ser-

\footnotetext{
th Ibidem. s. 4.

t7 Zob. Spiżamia.... k. E 1-E 3. Zasadniczo są to raczej fragmenty zawierające stosowną topikę, które można wpleść w tekst wlasncj oracji. z formalnego punktu widzenia nie można zaliczyé tych wzorów do odmiany .oddawanic picrścicnia”.
} 
cem, a małżeństwa pokonaną w paktach pokoju przysięgą, co w skok witać mogla, uprzejmie życza ${ }^{4+}$.

We wstępie mówca wprowadza topos pierścienia jako symbolu zwycięstwa, wzmocniony dodatkowo przykładem. W tej mowie, jak w wielı innych, milość opisywana jest w kategoriach walki, w której zwycięska jest panna, zaś kawaler, uznając się za pokonanego („zholdowanego"), poprzysięga narzeczonej dożywotnią wierność i oddanie. Jednak z punktu widzenia niniejszego artykułı istotny jest element umiejscawiający orację w obrzędzic, a więc fraza: „nim szczęśliwegro dojdzic terminu, dziś się w tym oddawa pierścieniu”. Wręczenie pierścienia (lub ich wymiana między narzeczonymi), czemu towarzyszyły stosowne przemówienia (mowa i dziękowanie), było jednoznaczne z przypieczętowanien planów matrymonialnych i ostatecznym potwierdzeniem woli obu stron. l'o zrękowinach pozostało podjęcie przygotowań do ślubu i wesela, a zatem zaproszenic gości, " przygotowanie uczty, prezentów, i oczywiście oracji, które miały zostać wygłoszone.

Prowadzone badania dowodzą, że obyczaj był modyfikowany i dostosowywany do konkretnej sytuacji. Ukazıją również, jak współczesne pojęcie dobrych maniè i grzeczności miało niewiele wspólnego z różnorodną praktyką siedemnastowieczną. Prośbę o zgodę na ślub wnoszono, nie bacząc na okoliczności, nawet jeśli były nimi śmierć albo pogrzeb najblizszych krewnych panny lub konkurenta. 1) wyrazenia zgody i do ślubu przymuszano czasem silą lub szantażem ${ }^{50}$. Negocjacje i ślub przeprowadzano z dnia na dzień, i tylko wesele odkladano na czas późniejszy, albo cały proces ciągnął siç latami. Kawaler mógł prosić przyjaciela o wygłoszenie oracji adresowanej do rodzica lub opiekuna, ale również mógł pominąć calą procedurę, i tak jak Jan Chryzostom Pasek przeprowadzić bardzo konkretną rozmowę z samą kandydatką, traktując opinię rodziny jako rzecz wtórną i muniej istotną̧ ${ }^{51}$. W sytuacjach trudnych, wymagających większej subtelności, można było uciec się do symboliki i gestu, aby uniknąć wyrażania expressis perbis nieprzyjemnych treści; gdy udzielano odmowy slownie, starano się wszakże miłymi wyrażeniami ocukrować porażkę.

\footnotetext{
48 K. Wojsznarowicz, op. cit. s. 2()2.

t9 Zaproszenia można bylo dokonać osobiścic lub piscmuic. Szczególowy opis kompozycji „listów wescelnych" i responsów na nie patrz M. Trębskia, op. cit., s. 132-135.

50) "U królaj[ego]m[ości] nikogo prawie nie było, aż w nocy pozjeżdżali siç i wlaśnie opontumissimnc [korzystnic]

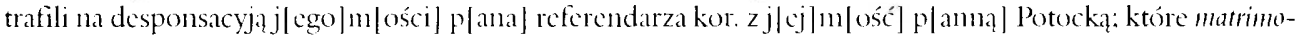
nimm niespodzicwanic siç stalo z przymusu prawic jmp. wojewodzincj kijowskicj. która chorując bardzo ciçz-

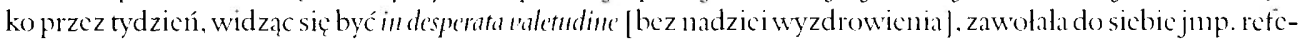
rendarza kor., tak długo puścić go od sicbie nic chciala, póki by mu nic pobłogosławiła przy ślubie, niżeli śmicré moc jej do tego odbicrze. Tak tedy gdy odwołać siç ab hor actu |od tego aktu| przynajmmicj do jutra nic mógl, consessit totum |zgodzil siç na wszystko]. Za którym konscuscm apula facta [po ustakonym polączenin\}] także u nicj przy lózkłı w tymze pokoju. gdzic chora leżała. bez zadnej ceremonijej jun. ks. poznański dat ślub. O czym inwitujący od królowej juz ks. jun. kardynal dowiedziawszy się, chcial ad candem benedictionem fo tym blogoshawieństwic] uprzedzić loci ardinarimm [micjscowego biskupa], ale juz przyjachal po harapic, skąd byl nicukontentowany" (K. Sarnecki, op. cit., s. 184).
}

5) Zob. J. Ch. Pasck, op. cit., s. 425-429. 
Dodać należy, że nawet pomyślnie zakończony proces od konkurów do zrękowin nie gwarantował bynajmmiej, że ślub się odbędzie:

Tego dnia odprawić się miało wesele jm panny Dubrawskiej siostrzenice mej zjmp Pokorszyńskim, sędzim gordzkim lidzkim, ale dla głupstwa pana młodego nie doszto ${ }^{52}$.

Zdarzały się też sytuacje niemal biblijne - podmieniano panny młode i wmawiano swatom, że o te wlaśnie była wnoszona uprzednio prośba ${ }^{53}$.

Wolno zatem powyższe rozważania nad rękopisami i drukami zakończyć refleksją: choć obficie utrwalono w nich liczne wzorce zachowań grzecznych i stosownych, udokumentowana praktyka staropolska wymyka siç wszelkim schematom, gdyż wzory zawsze pozostają tylko i wyłącznie wzorami.

\footnotetext{
52 S. Niczabitowski, Dziemnik 1695-1700, opr. A. Sajkowski, Poznań 1998, s. 72.

$\$ 3$ „Niedzicha zapustna [23 lutego 1658 - przyp. M. T.]. Na obiedzic byliśmy u pani Koszmidrowej, z którą prowadzilem rozmowy w sprawic dotrzymania obictnicy wydania za mąż Eufrozyny za pana [Eliasza Stefana] Bialokurowicza. Ona jednak twicrdzila. żc obiccala mu Jadwigę. W tym ujawnila się wyraźnie chytrość kobicty. o czym siç w zupelności przekonalem. (...) [2+ hutego 1658 - przyp. M. T.] Prowadziłem rozmowy w tej samcj materii, lecz ponicważ inaczej nic można jej bylo załatwić, więc za obopólną zgodą dalem pierścionck nic Eufrozynie. Lecz Jadwidze. [25lutego 1658- przyp. M. T. J Odbyl siç ślub Bialokurowicza i panny [Jadwigi] Koszmidrówny po uzyskaniu od j[aśnic] oś[ wieconego ] arcybiskupa lwowskiego zwolnienia od zapowiedzi“" (B. Rudomicz. op. cit.. s. 114). Faktem jest jednak, ze cytowany fragment dotyczy mieszczan zamojskich, nic zaś stanu szlacheckicgo).
} 